NBER WORKING PAPER SERIES

\title{
HIV AND FERTILITY IN AFRICA: FIRST EVIDENCE FROM POPULATION BASED SURVEYS
}

\author{
Chinhui Juhn \\ Sebnem Kalemli-Ozcan \\ Belgi Turan \\ Working Paper 14248 \\ http://www.nber.org/papers/w14248 \\ NATIONAL BUREAU OF ECONOMIC RESEARCH \\ 1050 Massachusetts Avenue \\ Cambridge, MA 02138 \\ August 2008
}

We thank Angus Deaton, Emily Oster, and the participants of the AIDS Workshop at Amsterdam Institute for International Development for valuable comments and suggestions. The views expressed herein are those of the author(s) and do not necessarily reflect the views of the National Bureau of Economic Research.

NBER working papers are circulated for discussion and comment purposes. They have not been peerreviewed or been subject to the review by the NBER Board of Directors that accompanies official NBER publications.

(C) 2008 by Chinhui Juhn, Sebnem Kalemli-Ozcan, and Belgi Turan. All rights reserved. Short sections of text, not to exceed two paragraphs, may be quoted without explicit permission provided that full credit, including $\odot$ notice, is given to the source. 
HIV and Fertility in Africa: First Evidence from Population Based Surveys

Chinhui Juhn, Sebnem Kalemli-Ozcan, and Belgi Turan

NBER Working Paper No. 14248

August 2008

JEL No. I12,J13,O12

\begin{abstract}
The historical pattern of the demographic transition suggests that fertility declines follow mortality declines, followed by a rise in human capital accumulation and economic growth. The HIV/AIDS epidemic threatens to reverse this path. A recent paper by Young (2005), however, suggests that similar to the "Black Death" episode in Europe, HIV/AIDS will actually lead to higher growth per capita among the affected African countries. Not only will population decline, behavioral responses in fertility will reinforce this decline by reducing the willingness to engage in unprotected sex. We utilize recent rounds of the Demographic and Health Surveys which link an individual woman's fertility outcomes to her HIV status based on testing. The data allows us to distinguish the effect of own positive HIV status on fertility (which may be due to lower fecundity and other physiological reasons) from the behavioral response to higher mortality risk, as measured by the local community HIV prevalence. We show that HIV-infected women have significantly lower fertility. In contrast to Young (2005), however, we find that local community HIV prevalence has no significant effect on non-infected women's fertility.
\end{abstract}

Chinhui Juhn

Department of Economics

University of Houston

Houston, TX 77204-5882

and NBER

cjuhn@uh.edu

Sebnem Kalemli-Ozcan

University of Houston

Department of Economics

Houston, TX 77204

and NBER

sebnem.kalemli-ozcan@mail.uh.edu
Belgi Turan

University of Houston

belgituran@gmail.com 


\section{Introduction}

The scope of the worldwide AIDS epidemic is staggering. As of 2008 there were an estimated 32 million people living with HIV/AIDS, with more then 90 percent of the infected people living in developing countries. Africa alone accounts for two-thirds of the world total and almost all of the infected children. The epidemic has altered the patterns of morbidity and mortality tremendously. What is the impact of HIV/AIDS epidemic on the future development of these affected countries? ${ }^{1}$

Drawing a parallel between AIDS and the "Black Death", Young (2005) suggests that population declines will lead to higher capital-labor ratios and eventually to higher per capita income in the affected countries. While the epidemic will have a detrimental impact on human capital accumulation, he postulates that widespread community infection will lower fertility, both directly through a reduction in the willingness to engage in unprotected sex, and indirectly, by increasing the scarcity of labor and the value of women's time. Using household data from South Africa and relying on between cohort variation in country level HIV infection and number of births, he estimates a large negative effect of HIV prevalence on fertility. He concludes that even under the most pessimistic assumption for human capital destruction the fertility effect dominates and hence future per capita income of South Africa improves. $^{2}$

Our study uses newly available micro data from population based surveys to examine the fertility response to HIV/AIDS. In the latest rounds of the Demographic Health Surveys

\footnotetext{
${ }^{1}$ Recent empirical papers show results that vary extensively. While most of the researchers find negative effects of the epidemic on economic growth, some find no effect and some even find positive effects. Bloom and Mahal (1997) run cross-country regressions of growth of GDP per capita on HIV/AIDS prevalence and find no effect. Papageorgiou and Stoytcheva (2007) find negative effect on the level of income per capita in a similar framework. Werker, Ahuja, and Wendell (2006) instrument HIV/AIDS prevalence by national circumcision rates and show that there is no effect of the epidemic on growth of the African countries. Corrigan, Gloom, and Mendez (2005) show calibration results that imply large negative effects of the epidemic on growth.

${ }^{2}$ Using similar household data on fertility from other African countries and HIV prevalence rate by country and time, Young (2007) reaches a similar conclusion. Kalemli-Ozcan (2007), on the other hand, reaches a different conclusion. Using both country level data from 50 African countries and also household data from South Africa in the 1990s, Kalemli-Ozcan (2007) finds that HIV/AIDS is positively related to fertility, both in the cross-section of countries, and in the household level data from South Africa for 1990s. In panel specifications with country fixed effects, however, Kalemli-Ozcan (2007) finds no effect of HIV on fertility.
} 
(DHS), HIV-testing was administered in 13 African countries allowing us to link an individual woman's detailed fertility and health history to her own HIV status. The advantages of this data are multi-fold. First, previously available data were based on samples of pregnant women attending prenatal clinics. Our data are based on a representative sample of the population. Second, since we have HIV status at the individual level, we can utilize individual level variation to examine the relationship between fertility and own HIV status. Young (2005, 2007) posits that the physiological effect of HIV on fertility are minimal and the predominant effect is through changes in behavior. We can come closer to distinguishing these two effects. We examine separately the effect of own HIV status on fertility (which may be due to lower fecundity and other physiological reasons) from the behavioral response of individual fertility to an increase in mortality risk, as measured by the community-level prevalence rates. It is important to distinguish between physiological and behavioral channels since decline in fertility that is isolated to already infected women will have a more limited impact on aggregate population changes compared to the case where behavioral changes among even the non-infected women reinforce the decline. On the other hand, the behaviorial response of non-infected women may be to increase fertility which will mitigate the diseases' negative impact on population. As discussed above, there is currently no agreement on even the direction of this behavioral response to increased mortality risk.

To preview our results, we find that the disease significantly lowers an infected woman's fertility. Being infected with HIV reduces births last year by approximately 20 to 21 percent. Our investigation of births prior to 1986 (prior to the on-set of the HIV/AIDS) using women's fertility histories suggests that unobserved heterogeneity is not driving our results. Our results suggest that the physiological impact of the disease may be important and play a predominant role to the extent that fertility declines. In contrast to Young (2005), however, we do not find a negative effect of local community HIV prevalence, our measure of mortality risk, on the fertility of non-infected women. In high HIV countries such as Kenya and Lesotho, the effect of community HIV prevalence on fertility of non-infected women is actually positive and statistically significant. However, when we pool all the countries we do 
not find a statistical significant effect. A major challenge is identification of the community mortality risk effect. Our data indicate that HIV infection is higher in urban areas with a more educated population and greater economic activity. Since these are areas that are likely to have higher wages and lower fertility rates, this will cause an attenuation bias on the estimates of the disease effect on fertility. For these reasons, we control for country and urban/rural residence, thereby identifying the community mortality risk effect through a comparison of regions within country and residence type. The addition of these controls however leads to large standard errors so that our community-level HIV effect is imprecisely estimated. For robustness, we use an alternative strategy and instrument the community level HIV prevalence with distance to the origin of the epidemic, the Democratic Republic of Congo, as suggested by Oster (2005). We also examine the relationship between fertility rates and community level prevalence rates in changes assuming zero prevalence of the disease before 1986 following Young (2005). Neither of these alternative strategies point to a significant community-level risk effect on non-infected women's fertility when we pool our 13 countries. Overall our estimate of the impact of HIV on total fertility rate is considerably smaller than reported in Young (2005). His estimates suggest that a community that has 100 percent prevalence would have fertility that is approximately 80 percent lower than a community with zero prevalence. Our estimate of the impact of HIV, working exclusively through the own effect, suggests that fertility would be approximately 20 percent lower.

The paper proceeds as follows. Section 2 reviews theoretical models that link fertility to mortality and also discusses the special case of HIV/AIDS. Section 3 describes the data. Section 4 presents the empirical results. Section 5 concludes.

\section{Conceptual Framework}

To begin, we can turn to the large theoretical literature that links life expectancy and economic development. Neoclassical growth models identify two effects. The first order effect of increased life expectancy is to increase population. Absent behavioral responses in 
fertility, reductions in mortality increase population, thus reducing capital-labor and landlabor ratios and depressing per capita income. This effect is offset to some degree if increased life expectancy, and more generally, better health, raises TFP and the rate of human capital accumulation. Models in the tradition of Becker and Barro (1988) that endogenize fertility show that fertility may respond to reinforce this latter effect towards higher investment and growth. ${ }^{3}$ Declines in mortality could lead to a quantity-quality trade-off where parents have fewer children but invest more in each child. These models suggest that fertility and mortality are positively related and behavioral response in fertility can undo and even reverse the initial rise in population size. ${ }^{4}$ The HIV/AIDS epidemic has generated a negative shock to life expectancy that threatens to reverse the path to growth laid out in these models. A key question, then, is the following: will fertility responses further reinforce, mitigate or even reverse the disease-induced population declines brought about by the HIV/AIDS crisis? ${ }^{5}$

In this section we review theoretical models that link fertility to mortality. Taking cue from the historical pattern of the demographic transition, these models predict an increase in fertility in response to a rise in mortality risk. We present a simplified version of the framework in Soares (2005) and Kalemli-Ozcan (2003) for illustration.

\footnotetext{
${ }^{3}$ See, for example, Cervellati and Sunde (2007), Tamura (2006), Soares (2005), Kalemli-Ozcan (2003), Galor and Weil (2000), Lucas (2000), and Ehrlich and Lui (1991).

${ }^{4}$ While not directly related to HIV/AIDS, a recent paper by Acemoglu and Johnson (2006) find no effect of life expectancy on level and growth of per capita income. They instrument changes in life expectancy with dates of global interventions in disease prevention. Their results suggest that an increase in life expectancy leads to an increase in population and fertility responses are insufficient to compensate. It may be the case, however, that many of the countries in their sample have not yet completed the demographic transition.

${ }^{5}$ While the focus of our study is the fertility channel, an equally important question is the effect of HIV/AIDS on human capital investment. A large number of papers cover this topic and generally find substantial negative effects. Meltzer (1992) argues that AIDS raises mortality of young adults, which is going to have the biggest effect on the rate of return on educational investment. He claims for a 30 percent HIV positive population like Botswana, there would be a 6 percent reduction in the rate of return to education relative to no HIV. Bell, Shantayanan, and Gersbach (2003), using household survey data from South Africa argue that the long-term economic costs of AIDS could be devastating because of the cumulative weakening from generation to generation of human capital. Fortson (2007), using data similar to ours, shows children currently growing up in Africa, including non-orphans, will complete 0.3 fewer years of schooling compared to the case of zero HIV prevalence.
} 


\subsection{Deterministic Survival}

Following Soares (2005) consider an economy inhabited by adult individuals who live for a deterministic amount of time and allocate their time between work, investing in their own education, and raising children. A fraction $\beta$ of children born die before reaching adulthood. Adults live for $T$ periods and derive utility from their own consumption, $c$ and from the human capital of their children, $h$, which is a linear function of their own human capital, $H$, given as $h=b H+d .{ }^{6}$ Parents also invest in their own human capital so that adult human capital production is given as, $H=e h_{0}+D$, where $h_{0}$ is the basic parental human capital inherited from own parents. Thus $b$ and $e$ represent time inputs into the production of children's and own human capital. ${ }^{7}$ Following the literature, the model assumes that the value parents place on the human capital of each child is a function of the number of children, $n$. In addition, the altruism function, $\rho$, also depends on child mortality $\beta$ and the longevity of the child as an adult, $T$. Abstracting from life cycle considerations and assuming discount and interest rates equal to zero, the lifetime maximization problem consists of the utility function and budget constraint below,

$$
\begin{aligned}
U(t) & =T \frac{c(t)^{\sigma}}{\sigma}+\rho(n, T, \beta) \frac{h^{\alpha}}{\alpha} \\
T H & =T c+n+(b n+e) H
\end{aligned}
$$

To present the static implications of longevity losses in partial equilibrium we use the first order conditions for maximization to show, ${ }^{8}$

$$
\frac{\partial \rho / \partial n}{\rho / n}=\epsilon(n, T, \beta)=\alpha
$$

Hence, the individual equates the elasticity of the altruism function with respect to the

\footnotetext{
${ }^{6}$ Note that we present only the partial equilibrium here. Economy wide production will be a function of adult human capital, $H$.

${ }^{7} d$ and $D$ represent innate human capital in the absence of any investments.

${ }^{8}$ See Soares (2005).
} 
number of children, $\epsilon(n, T, \beta)$, to the constant elasticity of the utility from human capital of children. Combining above equation with the altruism function and using the implicit function theorem gives,

$$
\frac{d n}{d T}=-\frac{\rho n-\frac{\partial \rho}{\partial T} \frac{\partial \rho}{\partial n} n}{\rho n\left[\frac{\partial^{2} \rho}{\partial n^{2}}-\frac{\partial \rho / \partial n}{\rho}\left(\frac{\partial \rho}{\partial n}-\frac{\rho}{n}\right)\right]}<0
$$

The sign follows from critical assumptions in the model. First, similar to others models in the literature, the elasticity of the altruism function in relation to $n$ is assumed to decrease, i. e., $\frac{\partial \epsilon}{\partial n}<0$. Second, it is assumed that parents see number of children and longevity of the children as substitutes, i. e., $\frac{\partial^{2} \rho}{\partial n \partial T}<0 .{ }^{9}$ The way we interpret this model in the context of HIV/AIDS is that the epidemic will cause a rise in child mortality, $\beta$ and decrease adult longevity $T$, thereby increasing the marginal utility of children. In addition, reductions in adult longevity reduces the return to adult human capital investment further reinforcing the rise in fertility.

\subsection{Uncertain Survival of Adolescents}

An alternative modeling strategy will rely on the uncertain survival of adolescents generated by the high mortality risk as argued by Sah (1991), Kalemli-Ozcan (2003), and Tamura (2006). The above framework abstracted from this type of uncertain survival in order to focus on the impact of adult longevity on the economic incentives faced by the individuals. However, in the context of HIV/AIDS, the uncertain survival of adolescents might have important consequences. The above modeling strategy underlines the fact that rising adult mortality shortens the time horizon of parents leading to a quality-quantity trade-off. At the same time, parents faced with a high mortality environment for young adults, may develop a precautionary demand for children due to uncertain survival and hence may choose to have more children and provide them with less education.

\footnotetext{
${ }^{9}$ The assumptions are justified based on evolutionary biology literature arguing preferences are shaped to maximize the long-run number of descendants. See Soares (2005) for details.
} 
Consider a similar structure as before, where parents have a total time of unity instead of, $T$. The difference is that here the number of survivors, $\mathrm{N}$, is a random variable. Parents get utility from their own consumption and from the total amount of the human capital of their survivors, where with the education investment in each child being, $e$, the human capital production function is given as $h=e^{\alpha} h_{0}$. Hence each child has a fixed cost, $v$, and an education cost but only some survive. The expected utility and the budget constraints are given as,

$$
\begin{array}{r}
U(t)=U(c(t))+E(U(N(t) h)) . \\
h(1-(v+e) n)=c .
\end{array}
$$

Let $q$ be the survival probability of each child, which is fixed over time. $N_{t}$, the number of survivors, is a random variable drawn from a binomial distribution. Thus, the probability that $N_{t}$ out of $n_{t}$ children will survive is,

$$
f(N ; n, q)=\left(\begin{array}{c}
n \\
N
\end{array}\right) q^{N}(1-q)^{n-N} \quad N=0,1, \ldots, n .
$$

Hence maximization becomes,

$$
E(U(t))=\sum_{N=0}^{n}\{[U(c(t))]+[U(N(T) h)]\} f(N ; n, q)
$$

This formulation implies that the number of children born and the number of surviving children are represented as nonnegative integers, which is a discrete representation. To have continuous representation we linearize around the mean and the variance and get the first order conditions, which will give us the following comparative static via the implicit function theorem, ${ }^{10}$

\footnotetext{
${ }^{10}$ See Kalemli-Ozcan, 2003.
} 


$$
\begin{aligned}
\frac{-\left(v+e_{t}\right)}{1-\left(v+e_{t}\right) n_{t}}+\frac{1}{n_{t}}+\frac{1(1-q)}{2 q n_{t}^{2}} & =0 \\
\frac{d n_{t}}{d q} & <0, \forall q .
\end{aligned}
$$

\subsection{The Special Case of HIV/AIDS}

We have so far considered HIV/AIDS as a shock to adult longevity, $T$ or to the uncertain survival probability of the child, q. However, there are characteristics of HIV/AIDS which suggests that this formulation is overly simplified. First, field evidence strongly suggests that there is a direct biological/physiological impact of the disease which lowers the fecundity of infected women, an effect which should be considered separately from the behavioral responses, as we have argued in the introduction. Many African studies, both clinic and cohort based, indicate lower fertility (around 40 percent) and childbearing odds among HIV positive woman. Gray et al. (1998), in a cross-sectional analysis of a Ugandan community, find an HIV induced reduction in fertility of 55 percent. Carpenter et al. (1997) and Hunter et al. (2003), in cohort studies in Uganda and Tanzania, respectively, find a 30-40 percent reduction in probability of becoming pregnant. Fecundity is reduced by HIV infection due to higher rates of miscarriage and stillbirth and high rates of co-infection with other sexually transmitted infections, which may cause secondary infertility. ${ }^{11}$

Second, since it is largely a sexually transmitted disease, we must consider how the disease impacts fertility through changes in sexual behavior, namely through the reduction in the willingness to engage in unprotected sex. The impact of the disease on sexual behavior in

\footnotetext{
${ }^{11}$ Young $(2005,2007)$ claims that the association between fertility and HIV cannot be explained by the physiological effects of the disease since medical studies cumulatively suggest a coefficient of about -0.43 in a regression of the $\ln$ ratio of infants to fecund women on the average infection rate. Young (2005) finds a coefficient of -1.63 and Young (2007) finds a coefficient of -1.60 . The size of these coefficients imply that a 100 prevalence rate would result in fertility that is 80 percent lower than the case of zero prevalence. However, as acknowledged in Young (2007) the results are sensitive to the time trend and hence sensitive to the sample. It is also acknowledged in Young (2007) that the coefficient of -1.63 would have been -0.86 if the entire South African sample of women aged 15 and above were used. The coefficient of -1.60 also goes down to -0.60 when country specific time trends were used in Young (2007).
} 
Africa has proven to be a much debated topic. Mwaluko et al. (2003), Bloom et al. (2000), Stoneburner and Low-Beer (2004), Lagarde et al. (1996), Lindan et al. (1991), Ng'weshemi et al. (1996), Williams et al. (2003), Caldwell et al. (1999) all find no change or very small change in sexual behavior. Luke and Munshi (2004) find that within Kenya, in a high AIDS prevalence environment married men are no different than single men in the number of non-marital partners. One would expect the number of non-marital partners to fall more for the married men if unprotected sexual activity is an issue or if wives could influence husband's extra-marital sexual activity. ${ }^{12}$ Oster (2005), using DHS data on sexual behavior from a subset of African countries finds that sexual behavior changed relatively little since the onset of the epidemic. She shows that there has been a very small decrease in the share of single women having premarital sex. Other researchers find some evidence of risky behavior reductions in Zambia and Zimbabwe such as reductions in multiple partners; see Cheluget et al. (2006), and Fylkesnes et al. (2001).

Oster (2005) suggests that the relatively little response in sexual behavior may be in part explained by low levels of knowledge about the disease. Data from DHS surveys show that the percentage of the female population that requests an HIV test, gets tested, and receives results is very small, the mean being 5.7 percent across 10 African countries with an average HIV prevalence of around 15 percent. The average level of comprehensive knowledge about the disease is only 30 percent. There is little systematic evidence that countries with higher prevalence have better knowledge. Recent evidence in Thornton (2006), however, suggests that knowledge alone may not account for the limited response of sexual behavior in many African countries. The paper is based on a randomized experiment in Malawi in which individuals were given monetary incentives to get tested and learn about their HIV status. Using randomized incentives as instrument for knowledge, she finds that those with positive HIV status were more likely to purchase condoms but by at most 2 condoms over a period of two months, and there was no change in behavior among those with negative HIV status.

\footnotetext{
${ }^{12}$ Sociologists have long argued that in Africa married women don't have a lot of power over their husband's extra-marital sexual activity.
} 
A recent paper by Oster (2007) also argues along these lines suggesting that shorter life expectancy and lower income could account for the large differences in behavioral response between individuals in Africa and the gay population in the U.S. Young (2005) strongly argues, on the other hand, that the reduction in willingness to engage in unprotected sex is a major component of the overall fertility response to HIV/AIDS.

Third, regardless of changes in sexual behavior and demand for unprotected sex, it may be the case that infected women who know their own status and have knowledge about mother-child transmission would want to reduce fertility rather than give birth to infected children. Again the evidence on this channel is mixed. Temmerman et al. (1990) find that in Nairobi a single session of counseling - which is common in most African countries - has no effect on the subsequent reproductive behavior of HIV-positive women. Allen et al. (1993) using cohort data from Kigali, Rwanda, find that in the first 2 years of follow-up after HIV testing, HIV-negative women were more likely to become pregnant than HIV-positive women. However, among HIV-positive women, those with no children were more likely to become pregnant than those with children and married women are more likely to become pregnant than unmarried women. The desire to have children among HIV-positive women altogether was 45 percent. On the other hand, Noel-Miller (2003) using panel data from Malawi shows that women who have higher subjective HIV risk perceptions for themselves were less likely to have children.

A body of theoretical models imply that fertility responds positively to a rise in mortality risk by increasing the marginal utility of having more children and reducing the returns to adult human capital or alternatively by inducing a precautionary demand for children. The special case of HIV/AIDS however suggests that fertility may decrease, first through direct physiological reasons, and second, through changes in sexual behavior and the reduction in willingness to engage in unprotected sex. In our empirical work below, we attempt to separate out the physiological and behavioral responses to the disease by distinguishing between the effect of own HIV/AIDS status versus the effect of mortality risk as measured by the community-level prevalence rate. 


\section{Data}

We use data from Demographic and Health Surveys (DHS), which are based on nationally representative samples. These surveys are designed to gather information on fertility and child mortality. Recent waves of these surveys have sought information on HIV/AIDS status by asking a subset of women who are interviewed to provide a few drops of blood for HIV testing. The collected blood specimens and the main surveys are linked by case identification numbers. The linked data are available for 13 out of the 16 countries who conducted the testing. Mali and Zambia have HIV data but cannot be linked to the main survey questions while Tanzanian survey does not include fertility questions. These countries were thus dropped from the analysis.

One caveat is that not all women were asked to give blood samples so that sample sizes are reduced. In addition, testing was voluntary so that some women refused to be tested, with the average response rate being approximately 94.2\%. Table 1 shows the response rates for the 13 countries in our sample. Altogether in our sample, out of a total of 131,575 women in the main DHS surveys, 64,062 women have non-missing HIV status variable. Since some women refused to be tested, there is concern that there may be selection into the tested group. Table 2 examines the possibility of selection bias by comparing observable characteristics such as age, education, marital status, residence type (urban/rural), and wealth quintile between women who refused to be tested and women who agreed to testing and thus have non-missing HIV status. The table reports the mean differences (refusers minus compliers). The comparison is conducted for each country. ${ }^{13}$ The table shows that the refusers are more likely to be educated, less likely to live in rural areas and more likely to be in the wealthiest quintile. Since we find a similar pattern when we compare HIV-positive and HIV-negative women among women with HIV status, this suggests that women with missing data are more likely to be HIV positive and our estimates of HIV prevalence may be too low in some countries.

\footnotetext{
${ }^{13}$ We have also compared the means pooling data from all countries which lead to similar qualitative conclusions.
} 
Table 3 compares the country-level HIV prevalence rates among 15-49 year old women from the DHS with HIV prevalence rates from other data sources. Column (1) presents the DHS data. Rates in column (3) are from UNAIDS and rates in column (4) are from the U.S. Census Bureau's HIV Surveillance Database. Column (5) presents U.S. Census Bureau's projections using the Estimation and Projections Package (EPP) from WHO/UNAIDS. EPP estimates HIV trends by fitting an epidemiological model to the surveillance data. ${ }^{14}$ The other sources largely rely on HIV prevalence among pregnant women attending pre-natal clinics. Timberg (2006) and many others argue that this method leads to an over-estimate of HIV prevalence because pregnant women, engaging in unprotected sex, have higher risk of HIV infection. The table shows that country level prevalence from other data sources are generally higher than those we estimate from the population based samples in the DHS. Note that this is true even for countries such as Malawi where there was a 100 percent response rate to testing. Plots of prevalence rates over time using U.S. Census Surveillance data (not reported here) shows that there is considerable year to year variation which calls into question the reliability of these data. While our tabulations here indicate that DHS estimates may be biased downwards due to the voluntary nature of the testing, in our view these data provide the most reliable and representative estimates of HIV prevalence rates.

\section{Empirical Results}

\subsection{Determinants of HIV Status}

Before we report our results on HIV and fertility, we first explore determinants of positive HIV status using individual level data. Table 4 reports the marginal probabilities and the associated standard errors from a reduced-form probit regression. The table shows that the relationship between HIV infection and education is non-linear with those with "no education" having the lowest infection rates. The relationship has an inverted-U shape with

\footnotetext{
${ }^{14}$ UNAIDS and U.S. Census data are used by Young (2005), Oster (2005), and Kalemli-Ozcan (2007), and the EPP projections are used by Young (2007) and Kalemli-Ozcan (2007).
} 
infection rates turning negative again at the highest education level, "tertiary education". Married women are more likely to be infected than never married women. "Formerly married" women, those who are widowed or divorced, have much higher infection rates. This most likely reflects the reverse causality with positive HIV status impacting marital status. Positive HIV status also varies by residence type with those in rural areas having lower infection rates. Wealth also matters with those who are in the "poorest" wealth quintile category having significantly lower propensity of being infected. One concern with using individual level data is that unobserved heterogeneity may influence both the propensity to contract the disease and fertility behavior. While our conditioning variables should take care of a large part of the problem, we return to this issue below.

\subsection{Effects of Own HIV Status on Fertility}

We begin by examining the effect of own HIV status on an individual woman's fertility. Our linear regression has the following form:

$$
\text { Fertility }_{i}=\alpha+\beta O w n H I V \text { Status }_{i}+\mathbf{X}_{i}^{\prime} \gamma+D_{c}+D_{\text {reg }}+D_{\text {res }}+\epsilon_{i},
$$

where we use birth in the last year, birth in the last 3 years, and birth in the last 5 years as our fertility variables. Own HIV Status is a dummy variable that takes a value of 1 if individual $\mathrm{i}$ is HIV positive, $\mathbf{X}_{i}$ is a vector of other covariates, and $\epsilon_{i}$ is a random error term. We include as individual controls age, education, marital status, dummies for wealth quintile, and the number of living children. We also add dummies for country, region and residence type (urban/rural) denoted as $D_{c}, D_{\text {reg }}, D_{\text {res }}$ respectively. While we run linear regressions as a starting point, the preponderance of zeros as well as the non-negative and discrete nature of the dependent variable suggests a Poisson specification may be more appropriate. We report estimates from both specifications below. ${ }^{15}$

\footnotetext{
${ }^{15}$ We therefore assume the number of births for a woman i, $Y_{i}$, follows a Poisson distribution, given the independent variables, $X_{1}, X_{2}, \ldots$

$$
\operatorname{Prob}\left(Y_{i}=y_{i}\right)=\frac{e^{-\mu_{i}} \mu_{i}^{y_{i}}}{y_{i} !}
$$
}


Table 5 shows the effect of own HIV status on fertility. The effect of having positive HIV status is negative and significant in all specifications. Column (1) indicates that positive HIV status lowers births last year by -.034. Since the average is .163 births (indicated in the bottom row of the table), this translates into a reduction of 21 percent. The Poisson estimates are reported in columns (4)-(6). The coefficients can be transformed into incidence rate ratios which are easier to interpret. These are reported in the bottom row of the table. According to column (4), positive HIV status reduces an infected woman's fertility last year by approximately 20 percent. The 3 and 5 year birth rates are reduced approximately 19 and 15 percents respectively. The table shows a sizeable negative impact of the disease on infected women's own fertility.

It is not clear to what extent these estimates reflect the pure physiological impact of the disease versus behavioral response among the infected women. Presumably, if the women are not aware of their own status this estimate reflects the pure physiological impact of the disease. On the other extreme, women who are infected may be fully aware of their own status, have complete knowledge of the disease including the transmission of the infection from mother to child and are purposefully avoiding giving birth to an infected child. In table 6 we explore whether including various measures of sexual behavior impacts the coefficient on HIV status. We repeat the same regressions as in table 5 but include an indicator variable for having more than one partner in the last 12 months, as well as an indicator variable for using a condom during last intercourse. The coefficients on condom use and having more than one partner is negative and statistically significant. However, the effect of positive HIV status remains similar to those in table 5, suggesting that physiological impact of the disease has a strong negative impact on fertility of infected women.

Unobserved heterogeneity may also be biasing the results. If women who are more likely to engage in risky sexual behavior have both higher propensity of being infected and have

where the log of the mean $\mu_{i}$ is assumed to be a linear function of the independent variables. That is,

$$
\ln \mu_{i}=\beta_{0}+\beta_{1} X_{1 i}+\beta_{2} X_{2 i}+\ldots
$$

A commonly cited problem with the Poisson distribution is that the variance is equal to the mean. 
lower desired fertility, this may cause a downward bias towards finding a negative effect. In table 7 we explore the role of unobserved heterogeneity and the question of whether women with positive HIV status are fundamentally different from those with negative status. Using the fertility histories of older women (aged 35-49) we examine the effect of current HIV status on births 20,15, 10, 5 years ago as well as births last year. In the top panel, Panel A, the dependent variable is births last year in the indicated year. In the bottom panel, Panel B, the dependent variable is the cumulative number of births up to the indicated year. Since the spread of HIV/AIDS was negligible prior to 1986, we would not expect a significant difference in births 20 years ago by current HIV status. Table 7 shows that there is no significant difference between HIV positive and negative women in births 20 or even 15 years ago. The difference in fertility of HIV positive and negative women, however, becomes more pronounced as the disease spreads over time. ${ }^{16}$ Table 7 bolsters our confidence that the own HIV status effect reported in table 5 is not driven by unobserved heterogeneity.

\subsection{Effects of Community HIV Prevalence on Fertility}

Results from the previous section suggests that being infected with the HIV virus has significant physiological impact, lowering the fertility of the infected women. While this is an important finding in its own right, we are also interested in how the disease prevalence and the rise in mortality risk affect behavior. ${ }^{17}$ To isolate the impact of the disease on behavior, we restrict our analysis in this section to women who are not infected. We run the following regression exclusively on women who are HIV negative:

$$
\text { Fertility }_{i r}=\alpha^{\prime}+\beta^{\prime} \text { CommunityHIV } V_{r}+\mathbf{X}_{i r}^{\prime} \gamma^{\prime}+D_{c}+D_{r e s}+\epsilon_{i r}^{\prime}
$$

\footnotetext{
${ }^{16}$ One possibility is that these women were too young 20 years ago to have pronounced differences in fertility behavior. We have also run the same regression using older women aged 40-49 and found very similar results.

${ }^{17}$ Note that the behavior does not have to be changed only as a response to the mortality risk posed by the disease and it can also be affected from the other effects of the disease like higher wages. However there is no evidence that wages and labor force participation is higher as a result of the disease so we ignore this channel for now.
} 
where $r$ refers to community (country by region by residence type (urban/rural) cell). Community HIV is defined as the fraction of all adults 15-49 (both men and women) with positive HIV status in a community. ${ }^{18}$ Since we control for both country and rural dummies (denoted as $D_{c}$ and $\left.D_{r e s}\right)$ in our regression, we are identifying the community HIV effect from crossregional differences in HIV prevalence and fertility within a country and within residence type. Before turning to the results, we report some descriptive statistics of communities in table 8 . As table 8 shows, community level HIV prevalence ranges from 0 to 36 percent with the average being approximately 6.3 percent.

We report the impact of community level HIV prevalence on non-infected women in table 9. Columns (1)-(3) report the effects on fertility when we specify the HIV prevalence rate in levels. Columns (4)-(6) report the results of an alternative specification when we specify the HIV prevalence rate in logs. ${ }^{19}$ As reported in columns (1) and (2), the sign on the community HIV effect switches from being positive for birth last year to being negative for birth last 3 years. The standard errors are large however, so that we cannot rule out either a positive or a negative effect. We conclude based on the OLS regression results in table 9 that we find little evidence of a significant positive or negative effect of community level HIV on non-infected women's fertility decisions. In the following section we report results from two alternative estimation strategies.

Our examination of HIV status at the individual level shows that women who are somewhat educated and live in urban areas are more likely to be infected. There are compelling reasons to believe that HIV infection is higher in areas with greater population density and economic activity. Our community HIV regression may suffer from an omitted variables bias in that communities that are the most economically active may have both higher infection rates and lower fertility, the latter being due possibly to the higher cost of women's time. To address this issue, we instrument community-level HIV prevalence with distance to the

\footnotetext{
${ }^{18}$ In a previous version of the paper, we used geographic sampling clusters instead of communities, which are more disaggregated. Although we got the same qualitative results, the fact that there are many zeros lead us to switch to communities.

${ }^{19}$ We lose 10 communities with zero prevalence when we use the log specification. We have also run the regression assigning a very small positive value to these communities and the results were very similar.
} 
origin of the epidemic, the Democratic Republic of Congo, as suggested by Oster (2005). For 4 of the 13 countries, the DHS reports the latitude and longitude of the geographic sampling cluster. Using this information we calculate distance to the center of the Democratic Republic of Congo. ${ }^{20}$ Table 10 reports the IV results. The bottom panel of table 10 shows the significant first-stage results with distance having a negative effect on community HIV prevalence. In columns (1)-(3) we specify the community prevalence rate in levels while the specification is in logs in columns (4)-(6). Despite the significant first-stage results, however, we do not find significant effect of community HIV prevalence on non-infected women's fertility in the second stage.

We have thus far relied on largely cross-regional variation to identify the community level HIV effect. This was due to the fact that we have a single cross-section of HIV status based on testing data and we view the reliability of the time variation in HIV prevalence as suspect (see Kalemli-Ozcan (2007)). However, Young (2005) and Young (2007) rely on changes in HIV prevalence over time focusing on between-cohort changes in fertility with the on-set of the disease. In the following section, we follow Young's methodology and utilize the fertility histories of individual women to arrange the data by age and year of birth. We introduce time variation in community-level HIV prevalence by assuming zero prevalence in the years prior to 1986. This strategy is also followed by Fortson (2007) in estimating the impact of community-level HIV prevalence on educational outcomes. More specifically, we run the following regression:

$$
\text { Fertility }_{i r t}=\alpha+\beta \text { CommunityHIV } V_{r t}+\mathbf{X}_{i t}^{\prime} \gamma+D_{c}+D_{\text {reg }}+D_{\text {res }}+\theta_{r}+\phi_{t}+\epsilon_{i r t}
$$

where $t$ refers to year of birth and is specified as two periods, 1981-1985 and 2001-2005. The dependent variable is births last year among HIV negative women. We include education,

\footnotetext{
${ }^{20}$ To calculate the distance to the center of Democratic Republic of Congo of the community defined by country, region, and urban/rural residence type, we average longitudes and latitudes reported in the sampling clusters included in the community.
} 
ever married dummy at time of birth, and age at birth effects. As always we control for country, region and residence dummies. We also have community fixed effects, time effects, age by time interactions in this specification. HIV prevalence varies by community and is assumed to be zero for all communities in 1981-1985. Controlling for other covariates, the coefficient $\beta$ measures whether fertility increased or decreased in communities with larger increases in HIV prevalence. The results are reported in table 11. We examine women aged 15-49 at birth in columns (1) and (3) and examine women aged 20-49 at birth in columns (2) and (4) in an effort to isolate women with completed schooling. The table shows the declining trend in fertility due to demographic transition since fertility is much lower in the later period, 2001-2005, relative to the earlier period, 1981-1985. This suggests that these countries were likely completing the demographic transition over this period. The table suggests that community HIV prevalence may actually be positively related to fertility changes although none of the coefficients are significant at the 5 percent level.

\section{Country by Country Results}

Next, we investigate both the own effect and the community effect running our previous regressions for each country instead of pooling them. Table 12 shows that with the exception of Cote d'Ivoire and Ethiopia the effect of own HIV status on the fertility of infected women seems to be strongly negative for each country. Table 13, on the other hand, shows mixed results for the community effect, which is consistent with the zero effect we find in the pooled regressions. For most of the countries we still get a zero effect. But for the two highest HIV countries in the sample, Kenya and Lesotho, we find a positive impact of community HIV on the fertility of non-infected women and for the two lowest HIV countries in our sample, Niger and Senegal, we find a negative effect or a mixed effect. As we have argued before the combination of the following two forces will lead to a downward bias and this bias might differ from country to country, which might explain the above results. First, there is a preHIV declining trend in fertility especially for the more developed countries since they were 
going through their demographic transition before being hit by AIDS. Second, these more developed countries/regions also have higher levels of HIV.

\section{The impact of HIV on the Total Fertility Rate}

Assuming that HIV has a zero impact on non-infected women, what is the impact of the infected women on aggregate total fertility rate? The basic answer to this question was already relayed in table 5 where we found that positive HIV status reduced births last year by approximately 20 percent. However, in the following table we put this in the context of the fertility levels and HIV prevalence rates of each country. The top row of table 14 reports the HIV prevalence rate for each country based on the HIV testing sample. The second row reports the TFR calculated from age-specific birth rates of all women with HIV status. The third row calculates the TFR using age-specific birth rates of HIV-negative women only. Finally, the last row corrects for differences in observable characteristics such as age, education, marital status, and wealth since our earlier tables showed differences in these characteristics between the HIV positive and HIV negative populations. ${ }^{21}$ Table 14 shows a wide range for the total fertility rates among the countries in our sample with TFR ranging from the low of 2.4 for Cote d'Ivoire to 7.1 for Niger. Comparing row (2) and (3), we see that there is virtually no impact on the aggregate fertility rate for countries with very low HIV prevalence rates. Even for high prevalence countries, such as Lesotho, Malawi and Zimbabwe, and Kenya, however, the total impact is relatively small. For example, for the highest prevalence country, Lesotho, which has a prevalence rate of 26.4 percent,

\footnotetext{
${ }^{21}$ To calculate the total fertility rate (TFR) for our sample of women with HIV status instead of all the women in DHS survey sample, we follow the method used by the DHS which uses information on births over the last 36 months for each woman based on the fertility histories. The numerator of each age-specific birth rate is the total number of births over the previous 36 months for women in each 5-year age category based on age at birth. The denominator is the total number of women-years in each 5 -year age category. Then we summed up all the age-specific fertility rates and multiply by 5 (since each woman is present in each age group for 5 years) to end up with the TFR as done by DHS. To adjust TFR for differences in observable characteristics between negative and positive HIV women, we run the own-HIV regression as specified in equation (8) and subtract the predicted effect of the observables before summing births among HIV-negative women.
} 
births would increase by .31 if all women were HIV negative. As expected the correction for observable characteristics dampens the fertility differences between infected and non-infected women and TFR would be only .15 higher with the correction. The main result in table 14 illustrates that without a large behavioral response among the non-infected women, the effect of HIV on aggregate fertility rate will be small and nowhere near the large negative impacted reported in Young (2005).

\section{Conclusion}

A body of theoretical models imply that fertility responds positively to a rise in mortality risk, either by reducing the returns to adult human capital or by inducing a precautionary demand for children. The special case of HIV/AIDS however suggests that fertility may decrease, first through direct physiological reasons, and second, through changes in sexual behavior and the reduction in willingness to engage in unprotected sex. To this date, there has not been robust evidence on this issue. The effect of HIV on fertility will be the key to evaluate the aggregate impact of the disease on economic development.

In our empirical work, we attempt to separate out the physiological and behavioral responses to the disease by distinguishing between the effect of own HIV/AIDS status versus the effect of mortality risk as measured by the community-level prevalence rate. We argue that it is important to distinguish these two effects since behavioral responses can further reinforce or possibly mitigate the population declines brought on by the disease. To this date this exercise could not be undertaken since the HIV testing data were not available and fertility behavior of infected and non-infected women could not be studied separately. We undertake this exercise for the first time by making use of the individual level HIV testing data that have recently become available.

Our results show that infected women are significantly less likely to give births than non-infected women. The probability of giving births in the previous year is approximately 20 percent lower. Robustness checks imply that these results are not driven by unobserved 
heterogeneity or different sexual behavior among the HIV positive women, suggesting that the disease significantly lowers the fecundity of the infected women. In contrast to Young (2005, 2007), however, we find no significant impact of community-level infection rates on fertility of non-infected women. Will the fertility responses to HIV reinforce or offset the declines in population due to mortality? Our results suggest that only fertility of infected women will decline and hence the total impact of HIV on the aggregate economy is much smaller than the effect implied by Young (2005) and (2007). Together with the results from other papers that document substantial declines in human capital accumulation, the results here suggest that HIV/AIDS is likely to decrease rather than increase future per capita incomes in Africa. 


\section{References}

Acemoglu, D., and S. Johnson, (2006). "Disease and Development: The Effect of Life Expectancy on Economic Growth", MIT, mimeo.

Allen, S., A. Serufilira, V. Gruber, S. Kegeles, P. Van de Perre, M. Carael, and T.J. Coates (1993).

"Pregnancy and Contraception Use among Urban Rwandan Women after HIV Testing and Counseling.", American Journal of Public Health, 83(5), 705-710.

Becker, G. S., R. J. Barro. (1988). "Reformulation of the Economic Theory of Fertility", Quarterly Journal of Economics 103(1):1-25.

Bell, C., Shantayanan, D., and H. Gersbach, (2003). "The Long-run Economic Costs of AIDS: Theory and Application to South Africa", University of Heidelberg, World Bank.

Bloom, S., C. Banda, G. Songolo, S. Mulendema, A. Cunningham, and J. T. Boerma, (2000). "Looking for Change in Response to the AIDS Epidemic: Trends in AIDS Knowledge and Sexual Behavior in Zambia, 1990 through 1998", Journal of Acquired Immune Deficiency Syndrome, 25(1), 77-85.

Bloom, D. and A. Mahal, (1997). "Does the AIDS Epidemic Threaten Economic Growth", Journal of Econometrics, 77(1), 105-124.

Caldwell, J., I. O. Orubuloyeb, and P. Caldwell (1999). "Resistances to Behavioural Change to Reduce HIV/AIDS Infection in Predominantly Heterosexual Epidemics in Third World Countries," Health Transition Centre.

Carpenter, L. M., J. S. Nakiyingi, A. Ruberantwari, S.S., Malamba, A. Kamali, J. A. G Whitworth (1997)., "Estimates of the Impact of HIV Infection on Fertility in a Rural Ugandan Population Cohort", Health Transition Review 7(2), 113126.

Cervelatti M., and U. Sunde, (2007). "Human Capital, Mortality, and Fertility: A Unified Theory of Economic and Demographic Transition," IZA, Working Paper 2905. 
Cheluget, B., G. Baltazar, P. Orege, M. Ibrahim, L. H. Marum, J. Stover, (2006). "Evidence for Population Level Declines in Adult HIV Prevalence in Kenya, " Sexually Transmitted Infections 82(1) , 121-126.

Corrigan, P., G. Gloom, and F. Mendez, (2005). "AIDS Crisis and Growth", Journal of Development Economics, 77(1), 107-124.

Ehrlich, I., and F. T. Lui, (1991). "Intergenerational Trade, Longevity, Intrafamily Transfers and Economic Growth", Journal of Political Economy, 99(5), 1029-1059.

Fortson, J., (2007). "Mortality Risk and Human Capital Investment: The Impact of HIV/AIDS in Sub-Saharan Africa", Working Paper.

Fylkesnes K., R. M. Musonda, M. Sichone, Z. Ndhlovu, F. Tembo, M. Monze, (2001). "Declining HIV Prevalence and and Risk Behaviors in Zambia: Evidence from Surveillance and Population-Based Surveys, " AIDS 15(7), 907-916.

Galor, O. and D. N. Weil (2000). "Population, Technology and Growth: From Malthusian Stagnation to the Demographic Transition and Beyond", American Economic Review, $90(4), 806-828$.

Gray, R. H., M. J. Wawer, D. Serwadda (1998). "Population-based study of fertility of women with HIV-1 infection in Uganda." Lancet 351(9096), 98-103.

Hunter, S. C., R. Isingo, J. T. Boerma, (2003). "The Association Between HIV and Fertility in a Cohort Study in Rural Tanzania, " Journal of Biosocial Science 35(1) , 189-199.

Kalemli-Ozcan, S., (2003). "A Stochastic Model of Mortality, Fertility and Human Capital Investment", Journal of Development Economics, 70(1), 103-118.

Kalemli-Ozcan, S., (2007). "AIDS, Reversal of the Demographic Transition and Economic Development: Evidence from Africa", NBER working paper 12181. 
Kremer, M. (1996). "Integrating Behavioral Choice into Epidemiological Models of the AIDS Epidemic, " Quarterly Journal of Economics 111(2), 549-573.

Lagarde, G., E. Pison and C. Enel (1996). "Knowledge, attitudes and perception of AIDS in rural Senegal: relationship to sexual behaviour and behaviour change, "AIDS, 10(3): $327-34$.

Lindan, C, S Allen, M. Carael, F. Nsengumuremyi, P Van de Perre, A. Serufilira, J. Tice, D. Black (1991). "Knowledge, Aattitudes, and Perceived Risk of AIDS Among Urban Rwandan Women: Relationship to HIV Infection and Behavior Change, "AIDS, , 5(8): 993-1002.

Lucas, R. E., Jr., (2000). "Some Macroeconomics for the 21st Century", Journal of Economic Perspectives, 14(1), 159-168.

Luke, N. and K. Munshi (2004). "New Roles for Marriage in Urban Africa: Sexual Activity and Labor Market Outcomes in Kisumu", Brown University, mimeo.

Meltzer, D., (1992). "Mortality Decline, the Demographic Transition and Economic Growth, " Ph. D Dissertation, University of Chicago.

Mwaluko, G., M. Urassa, R. Isingo, B. Zaba, and J. T. Boerma, (2003). "Trends in HIV and Sexual Behavior in a Longitudinal Study in a Rural Population in Tanzania, 1994-2000, " AIDS 17(18) , 2645-2651.

Ng'weshemi, JZ, JT Boerma, R. Pool, L. Barongo, K. Senkoro, M. Maswe R. Isingo, D. Schapink, (1996 "Changes in Male Sexual Behaviour in Response to the AIDS Epidemic: Evidence from a Cohort Study in Urban Tanzania," AIDS, , 10(12), 1415-20.

Noel-Miller, C. M., (2003). "Concern Regarding the HIV/AIDS Epidemic and Individual Childbearing, Evidence from Rural Malawi," Demographic Research,

Oster, E., (2005). "Sexually Transmitted Infections, Sexual Behavior, and the HIV/AIDS Epidemic", Quarterly Journal of Economics, 120(2), 467-515. 
Oster, E., (2007). "HIV and Sexual Behavior Change: Why Not Africa?", University of Chicago, mimeo .

Papageorgiou, C., and P. Stoytcheva, (2007). "What Do We Know About the Impact of AIDS on Cross-Country Income So Far?", Working Paper.

Sah, K. R, (1991). "The Effects of Child Mortality Changes on Fertility Choice and Parental Welfare, " Journal of Political Economy 99(3): 582-606.

Soares, R., (2005). "Mortality Reductions, Educational Attainment, and Fertility Choice", American Economic Review, 95(3), 580-601.

Stoneburner, R. and D. Low-Beer (2004). "Population-Level HIV Declines and Behavioral Risk Avoidance in Uganda, " Science, 304(5671), 714-718.

Tamura, R., 2006. "Human capital and Economic Development", Journal of Development Economics, 79(1), 26-72, .

Temmerman, M. S. M., Kiragu, D, Fusallah, S., Wamola, I. A. and Piot, P. (1990). "Impact of Single Session Post-partum Counselling of HIV Infected Women on Their Subsequent Reproductive Behavior, " AIDS 2(3), 247-252.

Thornton, R., (2006). "The Demand for and Impact of Learning HIV Status: Evidence from a Field Experiment, " Harvard University, Mimeo.

Timberg, C., (2006). "How AIDS in Africa Was Overstated", Washington Post.

UNAIDS/WHO (2003). Epidemiological Fact Sheets.

US Census Bureau (2003). HIV Surveillance DataBase.

Werker, E. D., Ahuja, A., and B. Wendell, (2006). "Male Circumcision and AIDS: The Macroeconomic Impact of a Health Crisis", HBS Working Paper. 
Williams, B., D. Taljaard, C. Campbell, E. Gouws, L. Ndhlovu, J. Van Dam, M. Carael, and B. Auvert, (2003). "Changing Patterns of Knowledge, Reported Behavior and Sexually Transmitted Infections in a South African Gold Mining Community", AIDS, 17(14), 2099-2107.

Young, A., (2005). "The Gift of the Dying: The Tragedy of AIDS and the Welfare of Future African Generations", Quarterly Journal of Economics, 120(2), 423-466.

Young, A., (2007). "In Sorrow to Bring Forth Children: Fertility amidst the Plague of HIV", Journal of Economic Growth, 12(4), 283-327. 
Table 1: HIV Testing Response Rates

\begin{tabular}{lccc}
\hline \hline & & & \\
& Testing Sample & Actually Tested & Response Rate \\
\hline Burkina Faso & 4422 & 4189 & 94.7 \\
Cameroon & 5391 & 5154 & 95.6 \\
Cote d'Ivoire & 8442 & 8428 & 99.8 \\
Ethiopia & 6812 & 5942 & 87.2 \\
Ghana & 5691 & 5289 & 92.9 \\
Guinea & 3847 & 3842 & 99.8 \\
Kenya & 4043 & 3271 & 80.9 \\
Lesotho & 3538 & 3020 & 85.4 \\
Malawi & 2864 & 2864 & 100.0 \\
Niger & 4441 & 4441 & 100.0 \\
Rwanda & 5663 & 5663 & 100.0 \\
Senegal & 5061 & 4465 & 88.2 \\
Zimbabwe & 7503 & 7494 & 99.9 \\
\hline \hline
\end{tabular}

Notes: The data are based on the following DHS surveys: Burkina Faso (2003), Cameroon (2004), Cote d'Ivoire (2005), Ethiopia (2005), Ghana (2003), Guinea (2005), Kenya (2003), Lesotho (2004), Malawi (2004), Niger (2006), Rwanda (2005), Senegal (2005), Zimbabwe (2005/2006)."Testing Sample" refers to the group of women who were asked to be tested. "Actually Tested" refers to the women who agreed to be tested. 


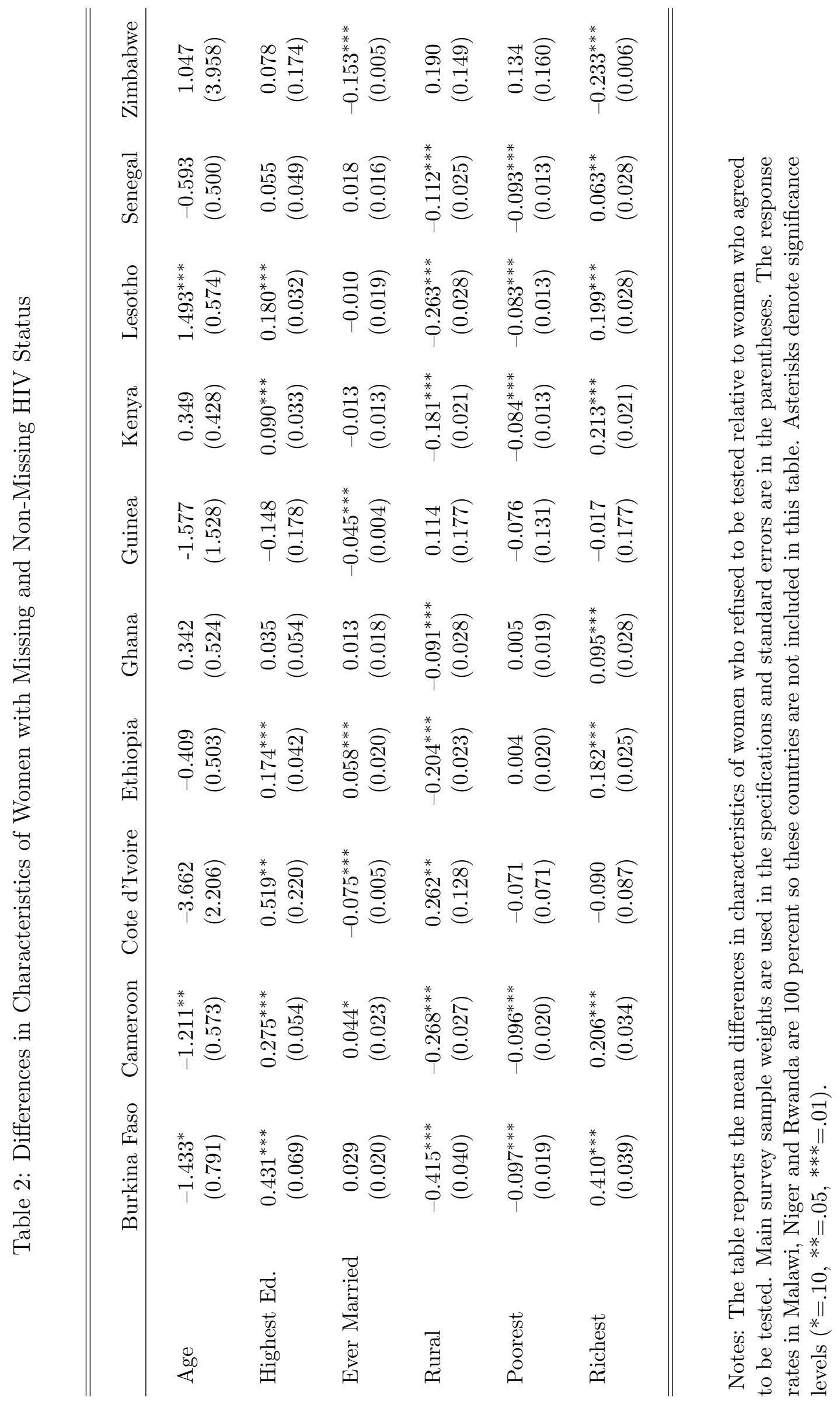


Table 3: HIV Prevalence Rates Across Countries: Different Sources

\begin{tabular}{|c|c|c|c|c|c|}
\hline Country & $\begin{array}{l}\text { DHS } \\
(1)\end{array}$ & $\begin{array}{c}\text { Survey Year } \\
(2)\end{array}$ & $\begin{array}{c}\text { UNAIDS/WHO } \\
(3)\end{array}$ & $\begin{array}{l}\text { US Census } \\
\text { (4) }\end{array}$ & $\begin{array}{c}\mathrm{EPP} \\
(5)\end{array}$ \\
\hline Burkina Faso & 1.8 & 2003 & 2.9 & 4.1 & 4.2 \\
\hline Cameroon & 6.6 & 2004 & 9.1 & 8.6 & 6.9 \\
\hline Cote d'Ivoire & 4.7 & 2005 & 9.1 & 3.0 & 7.0 \\
\hline Ethiopia & 1.9 & 2005 & 9.6 & 8.6 & 4.7 \\
\hline Ghana & 2.7 & 2003 & 3.7 & 1.7 & 2.2 \\
\hline Guinea & 1.9 & 2005 & 4.2 & 4.4 & 3.6 \\
\hline Kenya & 8.7 & 2003 & 12.0 & 11.1 & 6.7 \\
\hline Lesotho & 26.4 & 2004 & 31.0 & 28.0 & 28.7 \\
\hline Malawi & 13.3 & 2004 & 18.0 & 18.0 & 14.1 \\
\hline Mali & 1.8 & 2001 & 5.8 & 5.8 & 2.0 \\
\hline Niger & 0.7 & 2005 & 2.3 & 2.9 & 1.4 \\
\hline Rwanda & 3.6 & 2005 & 8.3 & 5.4 & 5.1 \\
\hline Senegal & 0.9 & 2005 & 1.7 & 0.8 & 0.9 \\
\hline Tanzania & 6.3 & 2003 & 8.1 & 17.5 & 8.6 \\
\hline Zambia & 19.7 & $2001 / 2002$ & 25.6 & 19.6 & 15.8 \\
\hline Zimbabwe & 21.1 & $2005 / 2006$ & 21.1 & 21.6 & 24.6 \\
\hline
\end{tabular}

Notes: Rates shown in column (1) are calculated using DHS HIV data including women ages 15-49 and weighted using HIV survey sample weights. Survey years are for Burkina Faso (2003), Cameroon (2004), Cote d'Ivoire (2005), Ethiopia (2005), Ghana (2003), Guinea (2005), Kenya (2003), Lesotho (2004), Malawi (2004), Mali (2001), Niger (2005), Rwanda (2005), Senegal (2005), Tanzania (2003) and Zambia (2001/2002), Zimbabwe (2005/2006). Column 2 reports the survey years. In columns (3)-(5), prevalence rates among pregnant women are reported and survey years are matched when available, otherwise the rates for nearby years are reported. Rates in column (3) are from UNAIDS/WHO Epidemiological Fact Sheets. In column (3), for Niger 2000, for Ghana 2002, for Cameroon, Ethiopia, Lesotho and Rwanda 2003, and for Cote d'Ivoire, Guinea and Zimbabwe 2004 HIV prevalence rates are reported. Column (4) is from US Census Bureau's HIV Surveillance Database (2006). In column (4), for Niger reported rate is for 2000, for Cote d'Ivoire, Cameroon, Ethiopia, Lesotho and Rwanda reported rates are for 2003, for Zimbabwe reported rate is for 2004. Column (5) presents US Census Bureau's projections using the Estimation and Projections Package (EPP) from WHO/UNAIDS. In column (5) all survey years are matched. Since HIV data for Mali and Zambia cannot be linked to main survey, and Tanzania survey does not contain fertility variables they are not used in the regressions, but prevalence rates are presented here for comparison purposes. 
Table 4: Determinants of HIV Status: Probit Regression

\begin{tabular}{lc}
\hline \hline & \\
Age & $\left(0.014^{* * *}\right.$ \\
& $-0.000^{* * *}$ \\
Age $^{2}$ & $(0.000)$ \\
& $0.011^{* * *}$ \\
Primary Education & $(0.003)$ \\
& $0.009^{* * *}$ \\
Secondary Education & $(0.003)$ \\
& $-0.010^{* *}$ \\
Higher Education & $(0.004)$ \\
& 0.004 \\
Currently Married & $(0.002)$ \\
& $0.080^{* * *}$ \\
Formerly Married & $(0.007)$ \\
Rural & $-0.013^{* * *}$ \\
& $(0.003)$ \\
Poorer & $0.011^{* * *}$ \\
& $(0.003)$ \\
Middle & $0.017^{* * *}$ \\
& $(0.003)$ \\
Richer & $0.020^{* * *}$ \\
& $(0.004)$ \\
Richest & $0.018^{* * *}$ \\
& $(0.004)$ \\
N & 0.241 \\
\hline \hline
\end{tabular}

Notes: Country and region dummies are included in the regression. The omitted categories are: "No Education", "Urban ", "Never Married", and "Poorest Wealth". The table reports marginal probabilities and associated standard errors. Asterisks denote significance levels $(*=.10, * *=.05, * * *=.01)$. 
Table 5: Effect of Own HIV Status on Fertility

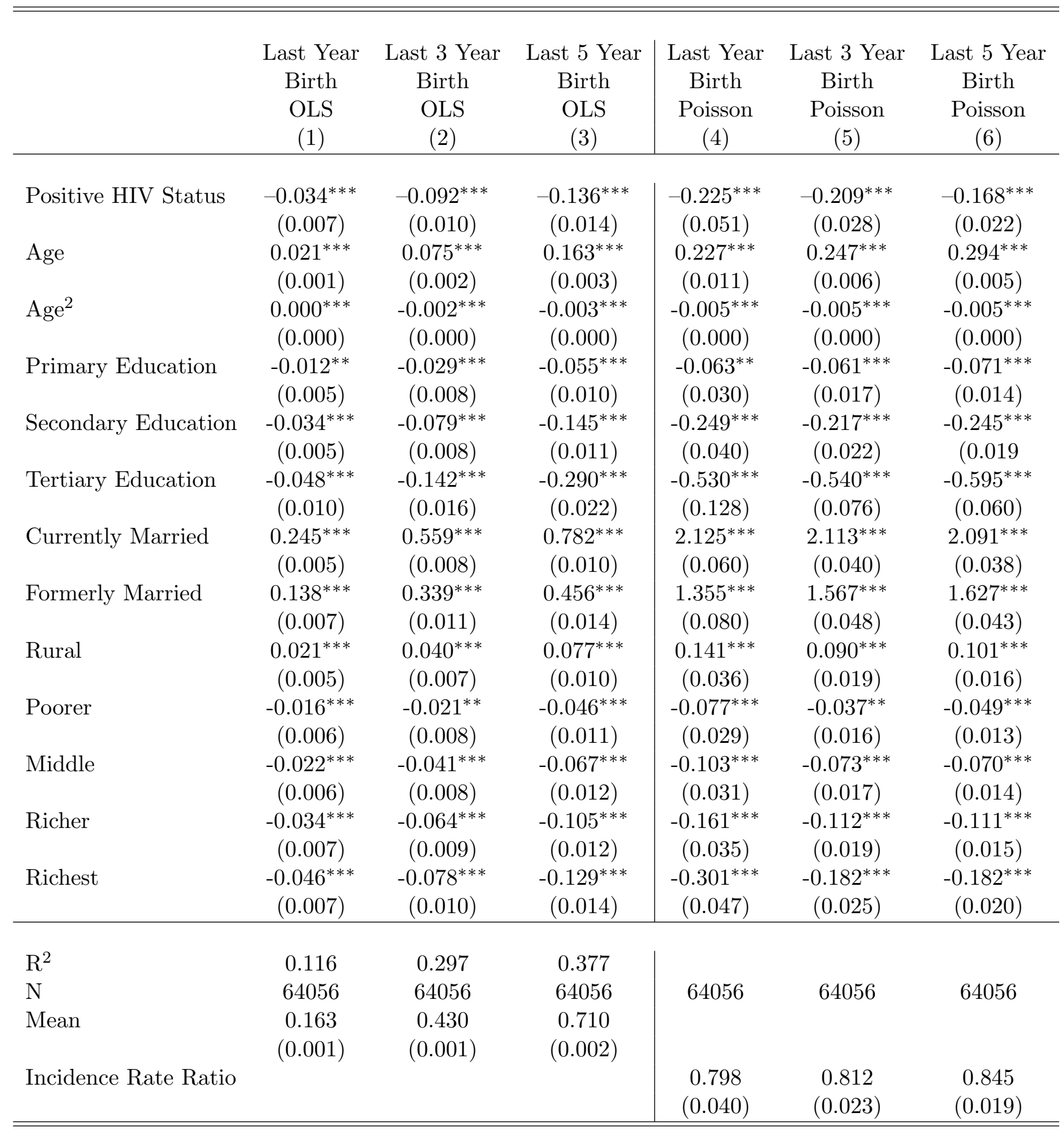

Notes: Women with non-missing HIV status are used in the regressions. All regressions include country and region dummies. The omitted categories are: "No Education", "Urban, "Never Married", and "Poorest Wealth" quintile. Columns (1) and (4) control for ngmber of living children last year, columns (2) and (5) control for number of living children 3 years ago, columns (3) and (6) control for number of living children 5 years ago. HIV survey sample weights are used in the regressions, and robust standard errors are in the parentheses. Asterisks denote significance levels $(*=.10, * *=.05, * * *=.01)$. 
Table 6: Effect of Own HIV Status on Fertility, Controlling for Number of Partners and Condom Use

\begin{tabular}{|c|c|c|c|c|c|c|}
\hline & $\begin{array}{c}\text { Last Year } \\
\text { Birth } \\
\text { OLS } \\
(1) \\
\end{array}$ & $\begin{array}{c}\text { Last } 3 \text { Year } \\
\text { Birth } \\
\text { OLS } \\
(2) \\
\end{array}$ & $\begin{array}{c}\text { Last } 5 \text { Year } \\
\text { Birth } \\
\text { OLS } \\
(3) \\
\end{array}$ & $\begin{array}{l}\text { Last Year } \\
\text { Birth } \\
\text { Poisson } \\
(4) \\
\end{array}$ & $\begin{array}{c}\text { Last } 3 \text { Year } \\
\text { Birth } \\
\text { Poisson } \\
(5) \\
\end{array}$ & $\begin{array}{c}\text { Last } 5 \text { Year } \\
\text { Birth } \\
\text { Poisson } \\
(6) \\
\end{array}$ \\
\hline Positive HIV Status & $\begin{array}{c}-0.038^{* * *} \\
(0.008)\end{array}$ & $\begin{array}{c}-0.101^{* * *} \\
(0.013)\end{array}$ & $\begin{array}{c}-0.152^{* * *} \\
(0.017)\end{array}$ & $\begin{array}{c}-0.228^{* * *} \\
(0.053)\end{array}$ & $\begin{array}{c}-0.212^{* * *} \\
(0.031)\end{array}$ & $\begin{array}{c}-0.177^{* * *} \\
(0.024)\end{array}$ \\
\hline Condom Use & $\begin{array}{c}-0.030^{* * *} \\
(0.007)\end{array}$ & $\begin{array}{c}-0.043^{* * *} \\
(0.011)\end{array}$ & $\begin{array}{c}-0.065^{* * *} \\
(0.015)\end{array}$ & $\begin{array}{c}-0.292^{* * *} \\
(0.069)\end{array}$ & $\begin{array}{c}-0.167^{* * *} \\
(0.039)\end{array}$ & $\begin{array}{c}-0.175^{* * *} \\
(0.032)\end{array}$ \\
\hline More Than One Partner & $\begin{array}{c}-0.073^{* * *} \\
(0.008)\end{array}$ & $\begin{array}{c}-0.153^{* * *} \\
(0.012)\end{array}$ & $\begin{array}{c}-0.203^{* * *} \\
(0.018)\end{array}$ & $\begin{array}{c}-0.522^{* * *} \\
(0.079)\end{array}$ & $\begin{array}{c}-0.413^{* * *} \\
(0.043)\end{array}$ & $\begin{array}{c}-0.321^{* * *} \\
(0.036)\end{array}$ \\
\hline $\mathrm{R}^{2}$ & 0.092 & 0.234 & 0.297 & & & \\
\hline $\mathrm{N}$ & 43965 & 43965 & 43965 & 43965 & 43965 & 43965 \\
\hline
\end{tabular}

Notes: Women with non-missing HIV status are used in the regressions. All regressions include country and region dummies. Other controls that are included are age, age squared, education, marital status, number of living children, wealth quintile. The omitted categories are: "No Education", "Urban", "Never Married", and "Poorest Wealth" quintile, "Did not use a condom during last intercourse", and "Did not have more than one partner in last 12 months". HIV survey sample weights are used in the regressions, and robust standard errors are in the parentheses. Asterisks denote significance levels $\left(*=.10,{ }^{* *}=.05,{ }^{* * *}=.01\right)$. 
Table 7: Effect of Own HIV Status on Fertility History

\begin{tabular}{|c|c|c|c|c|c|}
\hline & \multicolumn{5}{|c|}{ Panel A: Dependent Variable: Last Year Births } \\
\hline & Survey Year & 5 Years Ago & 10 Years Ago & 15 Years Ago & 20 Years Ago \\
\hline Positive HIV Status & $\begin{array}{c}-0.017^{* *} \\
(0.008)\end{array}$ & $\begin{array}{c}-0.027^{* *} \\
(0.011)\end{array}$ & $\begin{array}{c}-0.007 \\
(0.014)\end{array}$ & $\begin{array}{l}-0.013 \\
(0.015)\end{array}$ & $\begin{array}{l}-0.008 \\
(0.013)\end{array}$ \\
\hline Mean & $\begin{array}{c}0.109 \\
(0.002)\end{array}$ & $\begin{array}{c}0.177 \\
(0.003)\end{array}$ & $\begin{array}{c}0.220 \\
(0.003)\end{array}$ & $\begin{array}{c}0.251 \\
(0.003)\end{array}$ & $\begin{array}{c}0.206 \\
(0.003)\end{array}$ \\
\hline $\mathrm{R}^{2}$ & 0.053 & 0.087 & 0.042 & 0.034 & 0.077 \\
\hline $\mathrm{N}$ & 17696 & 17696 & 17696 & 17696 & 17696 \\
\hline
\end{tabular}

Panel B: Dependent Variable: Cumulative Number of Children Ever Born Survey Year 5 Years Ago 10 Years Ago 15 Years Ago 20 Years Ago

\begin{tabular}{lccccc} 
& Survey Year & 5 Years Ago & 10 Years Ago & 15 Years Ago & 20 Years Ago \\
Positive HIV Status & $-0.374^{* * *}$ & $-0.252^{* * *}$ & $-0.144^{* *}$ & -0.052 & -0.014 \\
& $(0.085)$ & $(0.078)$ & $(0.066)$ & $(0.051)$ & $(0.036)$ \\
& & & & & \\
\multirow{2}{*}{ Mean } & 5.367 & 4.748 & 3.746 & 2.531 & 1.315 \\
& $(0.022)$ & $(0.021)$ & $(0.019)$ & $(0.016)$ & $(0.012)$ \\
& & & & & \\
$\mathrm{R}^{2}$ & 0.332 & 0.355 & 0.400 & 0.462 & 0.507 \\
$\mathrm{~N}$ & 17696 & 17696 & 17696 & 17696 & 17696 \\
\hline \hline
\end{tabular}

Notes: Only women who are 35-49 are used in the regressions. In panel A dependent variable is the births previous year, in panel B dependent variable is cumulative number of children born for each woman up to $\mathrm{N}$ years ago from survey year. All women with HIV status are used in the regressions. All regressions include country and region dummies. The omitted categories are: "No Education", "Urban", "Never Married", and "Poorest Wealth" quintile. HIV survey sample weights are used in the regressions, and robust standard errors are in the parentheses. Robust standard errors are in the parentheses. Asterisks denote significance levels $(*=.10, * *=.05, * * *=.01)$. 
Table 8: Descriptive Statistics of Communities (County by region by residence type)

\begin{tabular}{lllll}
\hline \hline & & & & \\
Mean & Standard Deviation & Min & Max \\
\hline
\end{tabular}

Number of Communities $\mathrm{N}=244$

\begin{tabular}{lcccc} 
Number of Women & 539.24 & 503.81 & 41.00 & 5094.00 \\
Last Year Birth & 0.16 & 0.06 & 0.02 & 0.36 \\
Last 3 Year Births & 0.42 & 0.15 & 0.11 & 0.76 \\
Last 5 Year Births & 0.70 & 0.24 & 0.21 & 1.28 \\
HIV Prevalence & 0.063 & 0.076 & 0.000 & 0.359 \\
Know Someone Who Died of AIDS & 0.36 & 0.26 & 0.00 & 0.97 \\
Number of Communities Per Country & 18.77 & 4.82 & 6.00 & 25.00 \\
\hline \hline
\end{tabular}

Notes: HIV prevalence is based on both men and women samples. Births and knowledge variable refer women with HIV status. 
Table 9: Effect of Community HIV Prevalence on Fertility: OLS

\begin{tabular}{|c|c|c|c|c|c|c|}
\hline & $\begin{array}{c}\text { Last Year } \\
\text { Birth } \\
(1)\end{array}$ & $\begin{array}{c}\text { Last } 3 \text { Year } \\
\text { Birth } \\
(2)\end{array}$ & $\begin{array}{c}\text { Last } 5 \text { Year } \\
\text { Birth } \\
(3)\end{array}$ & $\begin{array}{l}\text { Last Year } \\
\text { Birth } \\
(4)\end{array}$ & $\begin{array}{c}\text { Last } 3 \text { Year } \\
\text { Birth } \\
(5)\end{array}$ & $\begin{array}{c}\text { Last } 5 \text { Year } \\
\text { Birth } \\
(6)\end{array}$ \\
\hline Community HIV Prevalence & $\begin{array}{c}0.206 \\
(0.162)\end{array}$ & $\begin{array}{c}-0.048 \\
(0.250)\end{array}$ & $\begin{array}{l}-0.228 \\
(0.407)\end{array}$ & & & \\
\hline Log Community HIV Prevalence & & & & $\begin{array}{l}-0.005 \\
(0.004)\end{array}$ & $\begin{array}{c}-0.012^{*} \\
(0.006)\end{array}$ & $\begin{array}{l}-0.005 \\
(0.004)\end{array}$ \\
\hline $\mathrm{R}^{2}$ & 0.116 & 0.304 & 0.384 & 0.116 & 0.304 & 0.385 \\
\hline $\mathrm{N}$ & 59579 & 59579 & 59579 & 58774 & 58774 & 58774 \\
\hline
\end{tabular}

Notes: Women with negative HIV status are included in the regressions. "Community HIV Prevalence" refers to the fraction of men and women with positive HIV status in cell defined by country, region and sector of residence, excluding the woman herself. Other controls are age, age squared, education, marital status, number of living children, wealth quintile, and country dummies. HIV survey sample weights are used in the regressions, and robust standard errors clustered at the country/region/sector level are in the parentheses. Asterisks denote significance levels $\left(*=.10,{ }^{* *}=.05, * * *=.01\right)$. 
Table 10: Effect of Community HIV Prevalence on Fertility: IV

\begin{tabular}{|c|c|c|c|c|c|c|}
\hline & $\begin{array}{l}\text { Last Year } \\
\text { Birth } \\
(1)\end{array}$ & $\begin{array}{c}\text { Last } 3 \text { Year } \\
\text { Birth } \\
(2)\end{array}$ & $\begin{array}{c}\text { Last } 5 \text { Year } \\
\text { Birth } \\
(3)\end{array}$ & $\begin{array}{c}\text { Last Year } \\
\text { Birth } \\
(4)\end{array}$ & $\begin{array}{c}\text { Last } 3 \text { Year } \\
\text { Birth } \\
(5)\end{array}$ & $\begin{array}{c}\text { Last } 5 \text { Year } \\
\text { Birth } \\
(6)\end{array}$ \\
\hline Community HIV Prevalence & $\begin{array}{c}0.649 \\
(0.728)\end{array}$ & $\begin{array}{l}-0.639 \\
(1.707)\end{array}$ & $\begin{array}{l}-2.007 \\
(2.830)\end{array}$ & & & \\
\hline $\begin{array}{l}\text { Log Community HIV } \\
\text { Prevalence }\end{array}$ & & & & $\begin{array}{c}0.045 \\
(0.066)\end{array}$ & $\begin{array}{c}0.017 \\
(0.098)\end{array}$ & $\begin{array}{l}-0.019 \\
(0.125)\end{array}$ \\
\hline Latitude & $\begin{array}{l}-0.001 \\
(0.003)\end{array}$ & $\begin{array}{l}-0.006 \\
(0.005)\end{array}$ & $\begin{array}{l}-0.012 \\
(0.008)\end{array}$ & $\begin{array}{c}0.005 \\
(0.010)\end{array}$ & $\begin{array}{l}-0.004 \\
(0.015)\end{array}$ & $\begin{array}{l}-0.014 \\
(0.020)\end{array}$ \\
\hline Longitude & $\begin{array}{l}-0.003 \\
(0.003)\end{array}$ & $\begin{array}{c}-0.016^{* *} \\
(0.007)\end{array}$ & $\begin{array}{c}-0.032^{* * *} \\
(0.009)\end{array}$ & $\begin{array}{c}0.003 \\
(0.012)\end{array}$ & $\begin{array}{l}-0.013 \\
(0.018)\end{array}$ & $\begin{array}{l}-0.031 \\
(0.021)\end{array}$ \\
\hline $\begin{array}{l}\mathrm{R}^{2} \\
\mathrm{~N}\end{array}$ & $\begin{array}{l}0.115 \\
14484\end{array}$ & $\begin{array}{l}0.299 \\
14484\end{array}$ & $\begin{array}{l}0.391 \\
14484\end{array}$ & $\begin{array}{l}0.112 \\
14277\end{array}$ & $\begin{array}{l}0.299 \\
14277\end{array}$ & $\begin{array}{l}0.393 \\
14277\end{array}$ \\
\hline & \multicolumn{6}{|c|}{ First Stage } \\
\hline Distance to Congo & & $\begin{array}{c}-0.031^{* * *} \\
(0.001)\end{array}$ & & & $\begin{array}{c}-0.526^{* * *} \\
(0.037)\end{array}$ & \\
\hline Latitude & & $\begin{array}{c}-0.001^{* * *} \\
(0.001)\end{array}$ & & & $\begin{array}{c}-0.152^{* * *} \\
(0.005)\end{array}$ & \\
\hline Longitude & & $\begin{array}{c}-0.004^{* * *} \\
(0.001)\end{array}$ & & & $\begin{array}{c}-0.184^{* * *} \\
(0.004)\end{array}$ & \\
\hline $\mathrm{R} 2$ & & 0.898 & & & 0.814 & \\
\hline
\end{tabular}

Notes: Women with negative HIV status are included in the regressions. "Community HIV Prevalence" and $\log$ of that are instrumented with distance between the cell (country/region/sector) and the center of the Democratic Republic of Congo. First stage results are reported at the bottom of the table. Regressions include controls for age, age squared, education, marital status, number of living children, wealth quintile, country and urban/rural dummies. HIV survey sample weights are used in the regressions, and robust standard errors clustered at the cell level are in the parentheses. Asterisks denote significance levels $(*=.10$, $* *=.05, * * *=.01)$. 
Table 11: Effect of Community HIV Prevalence on Last Year Birth: OLS

\begin{tabular}{lcc||cc}
\hline \hline & Ages 15-49 & Ages 20-49 \\
& $(1)$ & $(2)$ & $\begin{array}{c}\text { Ages 15-49 } \\
(3)\end{array}$ & $\begin{array}{c}\text { Ages 20-49 } \\
(4)\end{array}$ \\
\hline Community HIV Prevalence & 0.103 & -0.039 & & \\
& $(0.111)$ & $(0.096)$ & & \\
Log Community HIV Prevalence & & & $0.009^{*}$ & 0.004 \\
& & & $(0.005)$ & $(0.004)$ \\
$2001-2005$ & $-0.101^{* * *}$ & $-0.094^{* * *}$ & $-0.165^{* * *}$ & $-0.128^{* * *}$ \\
& $(0.010)$ & $(0.009)$ & $(0.042)$ & $(0.036)$ \\
Community Fixed Effects & Yes & Yes & Yes & Yes \\
$\mathrm{R}^{2}$ & 0.092 & 0.082 & 0.092 & 0.082 \\
$\mathrm{~N}$ & 309406 & 218862 & 309406 & 218862 \\
\hline \hline
\end{tabular}

Notes: Regressions only include HIV negative women. Dependent variable is the number of births last year. HIV Prevalence is assumed to be zero before 1985. Omitted categories are "1981-1985", "Ages 25-29", "No education", "Not married". In columns (3) and (4) prevalence rate is taken as 0.00001 at cells with 0 prevalence. All regressions include controls for education, marital status at birth, age group dummies, period dummies, age group by time interactions, and cell dummies. Robust standard errors are clustered at cell level and in parentheses. 
Table 12: Effect of Own HIV Status on Fertility Country by Country: OLS

\begin{tabular}{|c|c|c|c|c|c|c|}
\hline & $\begin{array}{c}\text { Last Year } \\
\text { Birth } \\
\text { OLS } \\
(1) \\
\end{array}$ & $\begin{array}{c}\text { Last } 3 \text { Year } \\
\text { Birth } \\
\text { OLS } \\
(2) \\
\end{array}$ & $\begin{array}{c}\text { Last } 5 \text { Year } \\
\text { Birth } \\
\text { OLS } \\
(3) \\
\end{array}$ & $\begin{array}{l}\text { Last Year } \\
\text { Birth } \\
\text { Poisson } \\
(4) \\
\end{array}$ & $\begin{array}{c}\text { Last } 3 \text { Year } \\
\text { Birth } \\
\text { Poisson } \\
(5) \\
\end{array}$ & $\begin{array}{c}\text { Last } 5 \text { Year } \\
\text { Birth } \\
\text { Poisson } \\
(6) \\
\end{array}$ \\
\hline Burkina Faso & $\begin{array}{l}-0.071 \\
(0.043)\end{array}$ & $\begin{array}{l}-0.095 \\
(0.078)\end{array}$ & $\begin{array}{c}-0.214^{* *} \\
(0.095)\end{array}$ & $\begin{array}{l}-0.466 \\
(0.362)\end{array}$ & $\begin{array}{l}-0.152 \\
(0.183)\end{array}$ & $\begin{array}{l}-0.214 \\
(0.131)\end{array}$ \\
\hline Cameroon & $\begin{array}{l}-0.027 \\
(0.024)\end{array}$ & $\begin{array}{c}-0.146^{* * *} \\
(0.034)\end{array}$ & $\begin{array}{c}-0.186^{* * *} \\
(0.047)\end{array}$ & $\begin{array}{l}-0.185 \\
(0.147)\end{array}$ & $\begin{array}{c}-0.348^{* * *} \\
(0.087)\end{array}$ & $\begin{array}{c}-0.244^{* * *} \\
(0.066)\end{array}$ \\
\hline Cote d'Ivoire & $\begin{array}{c}0.006 \\
(0.024)\end{array}$ & $\begin{array}{l}-0.006 \\
(0.038)\end{array}$ & $\begin{array}{l}-0.015 \\
(0.060)\end{array}$ & $\begin{array}{c}0.099 \\
(0.276)\end{array}$ & $\begin{array}{c}0.014 \\
(0.177)\end{array}$ & $\begin{array}{l}-0.015 \\
(0.157)\end{array}$ \\
\hline Ethiopia & $\begin{array}{c}-0.053 \\
(0.041)\end{array}$ & $\begin{array}{c}0.011 \\
(0.068)\end{array}$ & $\begin{array}{l}-0.115 \\
(0.083)\end{array}$ & $\begin{array}{l}-0.231 \\
(0.353)\end{array}$ & $\begin{array}{c}0.138 \\
(0.148)\end{array}$ & $\begin{array}{l}-0.051 \\
(0.127)\end{array}$ \\
\hline Ghana & $\begin{array}{l}-0.024 \\
(0.035)\end{array}$ & $\begin{array}{c}-0.111^{* *} \\
(0.050)\end{array}$ & $\begin{array}{c}-0.256^{* * *} \\
(0.063)\end{array}$ & $\begin{array}{l}-0.157 \\
(0.244)\end{array}$ & $\begin{array}{c}-0.270^{*} \\
(0.143)\end{array}$ & $\begin{array}{c}-0.392^{* * *} \\
(0.118)\end{array}$ \\
\hline Guinea & $\begin{array}{c}-0.091^{* * *} \\
(0.034)\end{array}$ & $\begin{array}{c}-0.157^{* *} \\
(0.072)\end{array}$ & $\begin{array}{c}-0.310^{* * *} \\
(0.102)\end{array}$ & $\begin{array}{c}-0.838^{* * *} \\
(0.371)\end{array}$ & $\begin{array}{c}-0.479^{* * *} \\
(0.241)\end{array}$ & $\begin{array}{c}-0.562^{* * *} \\
(0.202)\end{array}$ \\
\hline Kenya & $\begin{array}{l}-0.029 \\
(0.027)\end{array}$ & $\begin{array}{c}-0.079^{*} \\
(0.041)\end{array}$ & $\begin{array}{c}-0.101^{*} \\
(0.052)\end{array}$ & $\begin{array}{l}-0.174 \\
(0.156)\end{array}$ & $\begin{array}{c}-0.162^{*} \\
(0.095)\end{array}$ & $\begin{array}{l}-0.096 \\
(0.066)\end{array}$ \\
\hline Lesotho & $\begin{array}{c}-0.031^{*} \\
(0.017)\end{array}$ & $\begin{array}{c}-0.085^{* * *} \\
(0.024)\end{array}$ & $\begin{array}{c}-0.109^{* * *} \\
(0.032)\end{array}$ & $\begin{array}{c}-0.219^{*} \\
(0.127)\end{array}$ & $\begin{array}{c}-0.229^{* * *} \\
(0.074)\end{array}$ & $\begin{array}{c}-0.163^{* * *} \\
(0.056)\end{array}$ \\
\hline Malawi & $\begin{array}{c}-0.068^{* * *} \\
(0.023)\end{array}$ & $\begin{array}{c}-0.197^{* * *} \\
(0.033)\end{array}$ & $\begin{array}{c}-0.293^{* * *} \\
(0.047)\end{array}$ & $\begin{array}{c}-0.375^{* * *} \\
(0.128)\end{array}$ & $\begin{array}{c}-0.371^{* * *} \\
(0.069)\end{array}$ & $\begin{array}{c}-0.313^{* * *} \\
(0.056)\end{array}$ \\
\hline Niger & $\begin{array}{c}-0.121^{* *} \\
(0.061)\end{array}$ & $\begin{array}{c}-0.282^{* * *} \\
(0.094)\end{array}$ & $\begin{array}{c}-0.413^{* * *} \\
(0.154)\end{array}$ & $\begin{array}{l}-0.634 \\
(0.477)\end{array}$ & $\begin{array}{c}-0.477^{* *} \\
(0.234)\end{array}$ & $\begin{array}{c}-0.375^{*} \\
(0.199)\end{array}$ \\
\hline Rwanda & $\begin{array}{c}-0.063^{* * *} \\
(0.023)\end{array}$ & $\begin{array}{c}-0.077^{*} \\
(0.040)\end{array}$ & $\begin{array}{r}-0.074 \\
(0.059)\end{array}$ & $\begin{array}{c}-0.398^{* *} \\
(0.179)\end{array}$ & $\begin{array}{c}-0.148^{*} \\
(0.088)\end{array}$ & $\begin{array}{l}-0.082 \\
(0.074)\end{array}$ \\
\hline Senegal & $\begin{array}{l}-0.038 \\
(0.064)\end{array}$ & $\begin{array}{c}-0.183^{* *} \\
(0.072)\end{array}$ & $\begin{array}{c}-0.298^{* * *} \\
(0.091)\end{array}$ & $\begin{array}{l}-0.314 \\
(0.488)\end{array}$ & $\begin{array}{c}-0.548^{* *} \\
(0.257)\end{array}$ & $\begin{array}{c}-0.509^{* * *} \\
(0.181)\end{array}$ \\
\hline Zimbabwe & $\begin{array}{c}-0.031^{* *} \\
(0.012)\end{array}$ & $\begin{array}{c}-0.082^{* * *} \\
(0.018)\end{array}$ & $\begin{array}{c}-0.107^{* * *} \\
(0.023)\end{array}$ & $\begin{array}{c}-0.271^{* * *} \\
(0.096)\end{array}$ & $\begin{array}{c}-0.222^{* * *} \\
(0.048)\end{array}$ & $\begin{array}{c}-0.172^{* * *} \\
(0.035)\end{array}$ \\
\hline
\end{tabular}

Notes: Women with non-missing HIV status are used in the regressions. All regressions include region dummies. The omitted categories are: "No Education", "Urban", "Never Married", and "Poorest Wealth" quintile. Columns (1) and (4) control for number of living children last year, columns (2) and (5) control for number of living children 3 years ago, columns (3) and (6) control for number of living children 5 years ago. HIV survey sample weights are used in the regressions, and robust standard errors are in the parentheses. Asterisks denote significance levels $(=.10,=.05,=.01)$. 
Table 13: Effect of Community HIV Prevalence on Fertility Country by Country: OLS

\begin{tabular}{|c|c|c|c|c|c|c|}
\hline & $\begin{array}{c}\text { Last Year } \\
\text { Birth }\end{array}$ & $\begin{array}{c}\text { Last } 3 \text { Year } \\
\text { Birth }\end{array}$ & $\begin{array}{c}\text { Last } 5 \text { Year } \\
\text { Birth }\end{array}$ & $\begin{array}{l}\text { Last Year } \\
\text { Birth }\end{array}$ & $\begin{array}{c}\text { Last } 3 \text { Year } \\
\text { Birth }\end{array}$ & $\begin{array}{c}\text { Last } 5 \text { Year } \\
\text { Birth }\end{array}$ \\
\hline & \multicolumn{3}{|c|}{ HIV Prevalence } & \multicolumn{3}{|c|}{ Log HIV Prevalence } \\
\hline Burkina Faso & $\begin{array}{c}0.080 \\
(1.348)\end{array}$ & $\begin{array}{c}0.155 \\
(2.023)\end{array}$ & $\begin{array}{c}0.194 \\
(5.233)\end{array}$ & $\begin{array}{c}0.000 \\
(0.008)\end{array}$ & $\begin{array}{l}-0.003 \\
(0.014)\end{array}$ & $\begin{array}{l}-0.025 \\
(0.041)\end{array}$ \\
\hline Cameroon & $\begin{array}{l}-0.101 \\
(0.225)\end{array}$ & $\begin{array}{l}-0.141 \\
(0.675)\end{array}$ & $\begin{array}{l}-1.306 \\
(0.903)\end{array}$ & $\begin{array}{l}-0.002 \\
(0.007)\end{array}$ & $\begin{array}{l}-0.006 \\
(0.017)\end{array}$ & $\begin{array}{c}-0.039^{*} \\
(0.022)\end{array}$ \\
\hline Cote d'Ivoire & $\begin{array}{c}0.011 \\
(0.809)\end{array}$ & $\begin{array}{c}1.321 \\
(1.287)\end{array}$ & $\begin{array}{l}1.461 \\
(2.185)\end{array}$ & $\begin{array}{c}0.009 \\
(0.017)\end{array}$ & $\begin{array}{c}0.041 \\
(0.026)\end{array}$ & $\begin{array}{c}0.052 \\
(0.046)\end{array}$ \\
\hline Ethiopia & $\begin{array}{c}-4.617^{* * *} \\
(1.576)\end{array}$ & $\begin{array}{c}-5.424^{*} \\
(3.059)\end{array}$ & $\begin{array}{c}-8.480 * * * \\
(4.260)\end{array}$ & $\begin{array}{c}-0.032^{* * *} \\
(0.011)\end{array}$ & $\begin{array}{c}-0.042 \\
(0.025)\end{array}$ & $\begin{array}{l}-0.058 \\
(0.040)\end{array}$ \\
\hline Ghana & $\begin{array}{l}-0.425 \\
(0.363)\end{array}$ & $\begin{array}{c}0.530 \\
(0.599)\end{array}$ & $\begin{array}{c}1.382 \\
(0.863)\end{array}$ & $\begin{array}{c}-0.008^{*} \\
(0.004)\end{array}$ & $\begin{array}{l}-0.002 \\
(0.010)\end{array}$ & $\begin{array}{c}0.009 \\
(0.016)\end{array}$ \\
\hline Guinea & $\begin{array}{c}1.038 \\
(1.753)\end{array}$ & $\begin{array}{c}5.280 \\
(3.267)\end{array}$ & $\begin{array}{c}1.089 \\
(5.328)\end{array}$ & $\begin{array}{l}-0.017 \\
(0.022)\end{array}$ & $\begin{array}{l}-0.014 \\
(0.047)\end{array}$ & $\begin{array}{l}-0.106 \\
(0.066)\end{array}$ \\
\hline Kenya & $\begin{array}{c}0.676^{* * *} \\
(0.108)\end{array}$ & $\begin{array}{c}0.801^{* * *} \\
(0.315)\end{array}$ & $\begin{array}{c}1.310^{* * *} \\
(0.322)\end{array}$ & $\begin{array}{c}0.030^{* * *} \\
(0.006)\end{array}$ & $\begin{array}{c}0.035^{* *} \\
(0.015)\end{array}$ & $\begin{array}{c}0.066^{* * *} \\
(0.020)\end{array}$ \\
\hline Lesotho & $\begin{array}{c}0.579^{* *} \\
(0.291)\end{array}$ & $\begin{array}{c}0.406 \\
(0.495)\end{array}$ & $\begin{array}{c}1.567^{* *} \\
(0.725)\end{array}$ & $\begin{array}{c}0.072 \\
(0.036)\end{array}$ & $\begin{array}{c}0.041 \\
(0.064)\end{array}$ & $\begin{array}{l}0.178^{*} \\
(0.095)\end{array}$ \\
\hline Malawi & $\begin{array}{l}-0.075 \\
(0.210)\end{array}$ & $\begin{array}{l}-0.783 \\
(0.469)\end{array}$ & $\begin{array}{c}-1.303^{* * *} \\
(0.322)\end{array}$ & $\begin{array}{l}-0.005 \\
(0.009)\end{array}$ & $\begin{array}{l}-0.028 \\
(0.018)\end{array}$ & $\begin{array}{c}-0.052^{* * *} \\
(0.013)\end{array}$ \\
\hline Niger & $\begin{array}{l}3.297^{*} \\
(1.947)\end{array}$ & $\begin{array}{c}-8.004^{* *} \\
(3.777)\end{array}$ & $\begin{array}{c}-21.309^{* * *} \\
(5.765)\end{array}$ & $\begin{array}{c}0.012 \\
(0.008)\end{array}$ & $\begin{array}{c}-0.038^{*} \\
(0.020)\end{array}$ & $\begin{array}{c}-0.113^{* * *} \\
(0.022)\end{array}$ \\
\hline Rwanda & $\begin{array}{c}0.506 \\
(0.899)\end{array}$ & $\begin{array}{l}-0.252 \\
(1.143)\end{array}$ & $\begin{array}{l}-0.724 \\
(1.851)\end{array}$ & $\begin{array}{l}-0.007 \\
(0.021)\end{array}$ & $\begin{array}{l}-0.023 \\
(0.030)\end{array}$ & $\begin{array}{l}-0.045 \\
(0.046)\end{array}$ \\
\hline Senegal & $\begin{array}{c}-4.083^{* *} \\
(1.624)\end{array}$ & $\begin{array}{c}-6.441^{* *} \\
(3.042)\end{array}$ & $\begin{array}{c}-8.903^{*} \\
(4.726)\end{array}$ & $\begin{array}{c}-0.023^{* *} \\
(0.012)\end{array}$ & $\begin{array}{c}-0.023^{* *} \\
(0.012)\end{array}$ & $\begin{array}{c}-0.036^{*} \\
(0.021)\end{array}$ \\
\hline Zimbabwe & $\begin{array}{c}0.449 \\
(0.439)\end{array}$ & $\begin{array}{l}-0.243 \\
(0.520)\end{array}$ & $\begin{array}{l}-0.439 \\
(0.537)\end{array}$ & $\begin{array}{c}0.048 \\
(0.058)\end{array}$ & $\begin{array}{l}-0.049 \\
(0.071)\end{array}$ & $\begin{array}{l}-0.072 \\
(0.065)\end{array}$ \\
\hline
\end{tabular}

Notes: Women with negative HIV status are included in the regressions. "Community HIV Prevalence" refers to the fraction of men and women with positive HIV status in cell defined by country, region and residence type, excluding the woman herself. In columns (1)-(3) hiv prevalence is used, in columns (4)-(6) $\log$ hiv prevalence is used. Other controls are age, age squared, education, marital status, number of living children, wealth quintile. HIV survey sample weights are used in the regressions, and robust standard errors clustered at the cell level are in the parentheses. Asterisks denote significance levels $(*=.10, * *=.05, * * *=.01)$. 


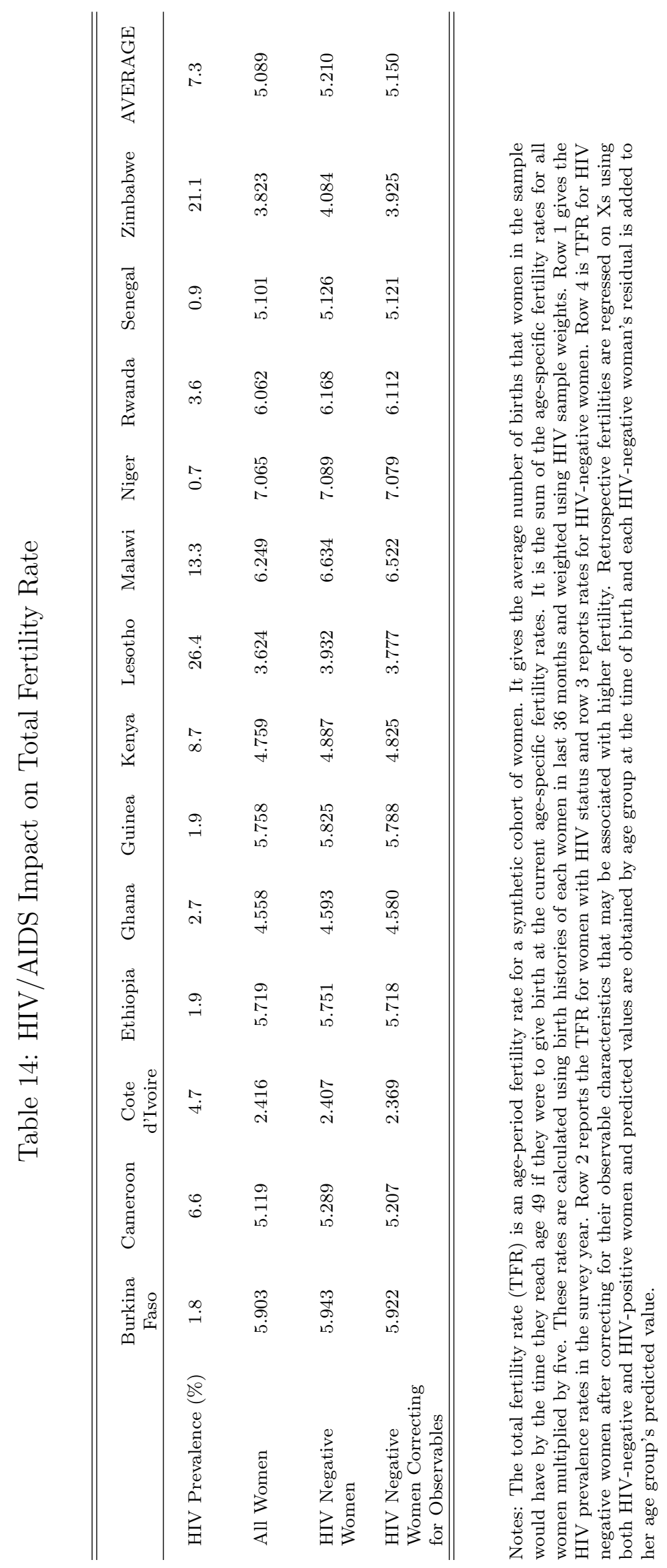

